\title{
STUDI FENOMENOLOGI : PENGALAMAN PASIEN PRIORITAS PALING RENDAH PADA KLASIFIKASI TRIAGE DI IGD RSUD DR. ISKAK TULUNGAGUNG
}

\author{
Elfi Quyumi R, Retty Ratnawati, Fransiska Imavike F
}

\begin{abstract}
While many patients present simultaneously, triage is an important function in the ER in sorting patients based on severity. Patients with lower priority will wait longer for assessment and treatment. The purpose of this study was to explore the experience of patient at the lowest priority in the emergency department. Methods of this research conducted with a qualitative approach appropriate design philosophy of Heidegger's interpretive phenomenology. Method using a semi-structured interview guidelines. Obtained from this purposive sampling technique 5 participants. Analysis of the data from this study uses an interpretive approach to the analysis of Van Manen found the core theme based comfortable for a patient in the ER. Experience this convenience in the form of five primary themes of experience in handling by workers, delivery of information by officers, ethics officers, environment and procedural in the ER. Based on these results it is recommended for health care workers in the emergency room to further improve communication, information, and education on patient lowest priority, or the formation of a special team that is responsible for communication problems.
\end{abstract}

Key words : patients with lower priority, experience, qualitative

\section{LATAR BELAKANG}

Masyarakat mengandalkan ruang gawat darurat untuk mencari pengobatan dan perawatan medis (AHCA, 2007), baik itu pada kondisi mengancam jiwa ataupun tidak. Pada pasien kronis dan tidak mengancam jiwa yang berobat ke ruang gawat darurat dapat mengkonsumsi sumber daya yang seharusnya digunakan untuk pasien akut dan mendesak (Afilalo, 2004; Vertesi, 2004; Carret, 2007). Hal tersebut juga yang mengakibatkan IGD dipenuhi pasien sehingga mengakibatkan pasien menunggu untuk mendapatkan pelayanan medis (AHCA, 2007).

Ketika banyak pasien hadir secara bersamaan, triage merupakan fungsi penting di IGD (ACEM, 2005) dalam memilah pasien berdasarkan kegawatan (Manitoba Health, 2010). Di dalam triage terdapat proses penilaian langsung dari pasien yang datang ke ruang gawat darurat (Brown et al, 2001). Semua pasien yang datang harus diprioritaskan oleh perawat berpengalaman khusus dan terlatih (Manitoba Health, 2010).
Triage yang akurat merupakan kunci untuk tindakan yang efisien di Instalasi Gawat Darurat (Manitoba Health, 2010). Penatalaksanaan pada kondisi darurat didasarkan pada respon klinis daripada urutan kedatangan (ACEM, 2005). Pasien dengan prioritas rendah akan menunggu lebih lama untuk penilaian dan pengobatan. (Manitoba Health, 2010).

\section{METODE PENELITIAN}

Metode yang digunakan dalam penelitian ini adalah penelitian kualitatif. Pendekatan yang digunakan adalah fenomenologi interpretative yang didasarkan pada filosofi Heidegger. Pemilihan partisipan dalam penelitian ini adalah pasien prioritas paling rendah pada klasifikasi triage, sehingga diharapkan bisa mengungkapkan pengalaman pasien di IGD.

Partisipan dipilih dengan tehnik purposive sampling. Kriteria inklusi pada penelitian adalah : pasien yang merupakan prioritas paling rendah di IGD RSUD Dr. Iskak Tulungagung, pasien baru pertama 
kali dirawat di IGD, serta pasien yang bersedia menjadi partisipan.

Pada saat wawancara, strategi yang digunakan adalah semi structure interview. Analisis data yang digunakan berdasarkan tahapan dari Van Manen. Sedangkan untuk proses keabsahan penelitian yang merupakan validitas dan reliabilitas dalam penelitian kualitatif ini dilakukan dengan tekhnik credibility, dependabiality, realibility, transferability, eksternal validity, dan comfirmability.

\section{HASIL}

Hasil analisis data didapatkan lima tema lama penanganan pasien, penyampaian informasi, etika petugas, lingkungan yang nyaman, dan prosedur yang berlaku. Lama penanganan pasien dibangun oleh waktu tunggu serta waktu periksa dan tindakan. Penyampaian informasi dibangun oleh informasi optimal dan informasi tidak optimal. Etika petugas dibangun oleh kewajiban petugas dan sikap petugas. Lingkungan yang nyaman dibangun oleh situasi kondusif dan kondisi ruangan. Prosedur yang berlaku dibangun oleh alur pasien dan manajemen obat.

\section{Lama penanganan pasien}

Penanganan pasien merupakan proses yang diperlukan petugas kesehatan dalam memenuhi kebutuhan pasien. Penanganan pasien membutuhkan waktu yang berbeda-beda tergantung dari rentang waktu saat mulai sampai saat mengakhiri suatu proses. Tema lama penanganan pasien, dibentuk dari dua sub tema yaitu : waktu tunggu dan waktu periksa dan tindakan.

Pasien tidak memerlukan waktu yang lama untuk dilakukan pemeriksaan oleh tenaga kesehatan di ruang triage kedua. Beberapa pasien harus menunggu untuk diperiksa karena kehabisan alat, sehingga langsung diperiksa di green zone, akan tetapi hal tersebut tidak menambah waktu tunggu pasien untuk pemeriksaan. Tidak diperlukan waktu yang lama bagi pasien untuk dilakukan pemeriksaan oleh tenaga kesehatan di ruang triage kedua. Keluarga memerlukan waktu yang lama untuk mendapatkan pelayanan pengambilan obat. Hal mengenai waktu tunggu pengambilan obat ditunjukkan dengan pernyataan :

P2 : "Yang menjadi kekurangan dari rumah sakit kemarin itu, pas mengambil obat itu, agak lama... ya mungkin petugasnya pas jam istirahat apa memang begitu, saya juga tidak tahu.."

P4 : "Tapi yang saya agak kecewa, antrinya obat lama, sampai nunggu pusing kepalanya...nunggu satu setengah jam untuk obat..."

\section{Penyampaian informasi}

Tema yang kedua pada proses analisis data yaitu penyampaian informasi. Penyampaian informasi dibentuk dari dua sub tema yaitu : informasi optimal dan informasi tidak optimal. Sub tema pertama dari penyampaian informasi yaitu informasi optimal. Informasi optimal terdiri dari lima kategori, yaitu : persetujuan tindakan, gambaran rasa sakit, pasien bertanya, respon pasien, keluarga dipanggil. Sedangkan informasi tedangkan informasi tidak optimal meliputi enam kategori, yakni : dicatat di buku, diam, bingung baca dosis, memikirkan penyakit, langsung dilakukan tindakan, serta tidak ada informasi perencanaan pulang.

Pada saat dilakukan pemeriksaan, partisipan tidak diberikan penjelasan mengenai pemeriksaan apa yang akan dilakukan dan tujuan dari pemeriksaan tersebut. Seperti halnya pada saat pemeriksaan dan tindakan, partisipan tidak diberikan penjelasan mengenai penyakit atau kondisi yang dialaminya pada saat itu. Hal ini dinyatakan dalam pernyataan :

P4 : "Tadinya diam saja, saya tidak tanya..juga diam...trus saya tanya..baru dikasih tau sakit paruparu gitu pulang tambah bingung..mikir penyakitnya 
gimana, harus berobat dimana?harus diteruskan itu.. ato? Harus cari?biasanya kan itu, anu apa itu .. itu lo.. pengobatan alternatif, kan banyak disini"

P5 : "kecewanya tadi mbak, katanya habis diperiksa dokter, katanya hasilnya ditunjukkan sakitnya apa...trus saya tanya mas, Kok gak dingomongne loro $\mathrm{ku}$ kuwi opo to mas.. yo mboh, yo ngono kuwi paling..(kok tidak diberitahu penyakit saya apa ya mas)..."

\section{Etika petugas}

Tema etika petugas terdiri dari sub tema yaitu kewajiban petugas dan sikap petugas. Sub tema kewajiban petugas terdiri dari tiga kategori, yaitu tanggung jawab petugas, pemenuhan kebutuhan pasien, dan ketrampilan petugas. Tanggung jawab petugas dalam memberikan pelayanan kepada pasien, dinilai cukup baik oleh partisipan. Hal tersebut dibuktikan dengan pernyataan :

P3 : "Baguslah kayak gitu, maksudnya pasien datang langsung ditangani. mboten wonten kelalean kayak dulu (tidak ada kelalaian seperti dulu)..Kalo dulu pasien masuk tidak langsung ditangani. Dulu tahun 2005 atau 2006 pas ngantar nenek, selalu diabaikan..."

Kategori dari sub tema sikap petugas adalah perilaku pasien (cepat bertindak, sopan, ramah, dan menghargai) serta tidak ada pembedaan status pasien. Pasien di IGD datang dengan berbagai macam jenis karakteristik dan latar belakang, hal tersebut tidak merubah respon petugas dalam penanganan pasien, dibuktikan dengan pernyataan :

P4: “...sepertinya sama
perlakuannya, pokoknya tidak ada
perbedaan meskipun pasien
Jamkesmas..."

\section{Lingkungan yang nyaman}

Lingkungan yang nyaman dibentuk dari dua sub tema yaitu : kondisi ruangan dan situasi kondusif. Kondisi ruangan terdiri dari dua kategori yaitu : bersih, dingin, dan teratur serta tidak ada bau obat. Gedung IGD yang sekarang ditempati, merupakan bangunan yang baru selesai dalam pembangunan. Partisipan merasakan kenyamanan ketika memasuki dan tinggal beberapa saat untuk dilakukan tindakan di ruangan, dengan dibuktikan oleh pernyataan:

P3 : "Sekarang sudah bagus semua..pelayanan, perobatan, bau obat sudah tidak ada.. kalau dahulu memang ya bau obat yo... masyaAlloh. sekarang sudah bagus tidak seperti dulu.. perubahannya pun banyak sekali.."

Situasi kondusif merupakan sub tema kedua setelah kondisi ruangan pada tema lingkungan yang nyaman. Situasi kondusif terdiri dari empat kategori yaitu : perasaan nyaman, pembicaraan petugas, penunggu di luar, dan privasi pasien terjaga. Situasi yang kondusif dirasakan partisipan ketika menjalani perawatan di IGD, dibuktikan dengan pernyataan :

P3 : "Tidak ada orang yang keluar masuk..kadang-kadang kan orang masuk untuk besuk.."

P5 : "Ya terasa nyaman lah, kan anu yang ikut anu itu disuruh keluar, kan cuma pasien yang ada di dalam..."

\section{Prosedur yang berlaku}

Tema yang terakhir pada proses analisis data yaitu prosedur yang berlaku. Prosedur yang berlaku dibentuk dari dua sub tema yaitu : alur pasien dan manajemen obat.

Alur pasien merupakan sub tema pertama dari prosedur yang berlaku. Alur pasien terdiri dari tiga kategori, yaitu : proses administrasi, proses pendaftaran, serta persyaratan Jamkesmas. Proses pendaftaran di IGD tidak dijelaskan baik 
itu secara verbal maupun tertulis, hanya terdapat tulisan yang menunjukkan masing-masing ruangan di IGD. Hal ini dinyatakan dalam pernyataan :

P3 : "Tidak ada lima menit, duduk sebentar terus langsung dipanggil, Panggilannya langsung suruh masuk ke triage kedua ..? ndak ada yang mengarahkan, Kan sudah ada tulisannya, tidak ada petugas, sudah diarahkan sama tulisannya...ya langsung masuk aja..."

P4 : “Waktu masuk ya cuma dianu.. dibawa ke sana kesana gitu.."

Manajemen obat merupakan sub tema kedua dari prosedur yang berlaku. Manajemen obat terdiri dari tiga kategori, yaitu : proses pengambilan obat, jumlah petugas, dan apotik yang dijadikan satu dengan rawat inap. Hampir seluruh partisipan menyebutkan bahwa tidak nyaman dengan managemen pengambilan obat, dikarenakan proses pengambilan obat yang lama dan dijadikan satu dengan pasien rawat jalan, seperti dalam pernyataan

P2 : "Antrinya agak lama. Alangkah baiknya jika apotiknya dan petugasnya dipisah. Yang satu rawat inap dan rawat jalan. Kalau pasien rawat inap kan tidak masalah, kan sudah di sana. biar cepat..Yang kasihan, rawat jalan, kalau mau cepat ingin pulang kan nunggu lama kasihan..nanti disendirikan kan bisa...yang rawat jalan kan ingin cepat pulang “

\section{PEMBAHASAN}

\section{Lama penanganan pasien}

Penanganan adalah proses, cara, perbuatan menangani; penggarapan. Penanganan pasien merupakan proses menangani semua kebutuhan pasien mulai pasien masuk rumah sakit sampai dengan pasien pulang ke rumah. Waktu tunggu di Indonesia ditetapkan oleh Departemen
Kesehatan melalui standar pelayanan minimal. Setiap rumah sakit harus mengikuti standar pelayanan minimal tentang waktu tunggu ini. Standar pelayanan minimal di rawat jalan berdasar Kemenkes No Nomor 129/ Menkes/ SK/ II/2008 adalah kurang atau sama dengan 60 menit.

Tindakan kenyamanan (comfort measures) menurut Kolcaba memerlukan sekurang-kurangnya tiga tipe intervensi comfort, yaitu : tindakan standar untuk kenyamanan (mempertahankan atau mengembalikan kenyamanan), mengajarkan (memberikan harapan dan menurunkan kecemasan), serta tindakan penguatan untuk kenyamanan jiwa (Tomey, 2006). Tindakan penguatan kenyamanan jiwa dapat diwujudkan dengan segera mengatasi keluhan pasien. Seperti yang disampaikan partisipan kedua

"Orang sakit, sudah sembuh kan pengen cepat pulang ... kalau cepet, senang. Kalau sakit senang kan terobati, ga usah dikasih obat sudah terobati.."

\section{Penyampaian informasi}

Komunikasi merupakan salah satu media dalam penyampaian informasi. Keakuratan informasi yang diperoleh tergantung dari bagaimana komunikasi diberikan kepada lawan bicara. Komunikasi di IGD memang berbeda dengan komunikasi di ruangan rawat inap, komunikasi yang efektif lebih mudah diterapkan pada kondisi ini. Komunikasi efektif ditandai dengan menjadi jelas, lengkap, akurat, tepat waktu, dan memerlukan verifikasi dari pihak yang terlibat (Spencer, et al, 2002). Komunikasi yang efektif dapat dimodifikasi melalui proses komunikasi secara sekunder. Proses komunikasi secara sekunder merupakan proses penyampaian pesan oleh komunikator (pihak rumah sakit) kepada komunikan (pasien atau keluarga pasien) dengan menggunakan alat atau sarana sebagai media kedua (Rakhmat, 2005), yaitu berupa baliho atau pamflet, 
yang dapat dibaca pengunjung IGD sehingga informasi mudah diterima.

Kurangnya komunikasi atau tidak ada informasi antara penyedia perawatan dan pasien merupakan tema yang sering muncul di IGD. Pasien sering mengalami mis diagnosis atau ketidaktahuan tentang penyakitnya (Ackerman, et al. 2012). Kemampuan memprediksi akurasi informasi yang akan disampaikan dengan waktu terbatas dalam konteks kegawatdaruratan dengan lingkungan yang sibuk menjadi bahan pertimbangan bagi penyampai informasi, ditambah kondisi beban kerja yang tidak terduga, keadaan ramai, perawatan simultan untuk beberapa pasien (Eisenberg, 2005). Pasien datang ke IGD tidak hanya ingin mendapatkan kesembuhan secara fisik, tetapi juga kejelasan tentang kondisi tubuhnya, bagaimana perkembangan kesehatannya. Pemberian informasi tentang keadaan pasien, akan mengurangi kebingungan pasien dalam merasakan penyakitnya dan memutuskan tindakan yang terbaik guna mencapai kondisi yang optimal. Kurangnya komunikasi dan transfer informasi dapat mempengaruhi perawatan pasien (Krispalani, 2007). Seperti halnya pada saat pemeriksaan dan tindakan, pada partisipan tidak diberikan penjelasan mengenai penyakit atau kondisi yang dialaminya ketika dirawat di IGD.

Salah satu tindakan kenyamanan (comfort measures) menurut Kolcaba memerlukan yaitu : mengajarkan (memberikan harapan dan menurunkan kecemasan) (Tomey, 2006). Mengajarkan merupakan salah satu tindakan perawat dalam memberikan harapan dan menurunkan kecemasan, Mengajarkan merupakan salah satu bentuk penyampaian informasi. Pasien yang mengetahui kondisi atau keadaannya melalui informasi yang akurat, akan lebih kooperatif terhadap semua tindakan yang diberikan kepadanya, yang pada akhirnya berdampak terhadap kesembuhan baik dari segi fisik maupun psikologis.

\section{Etika petugas}

Etika petugas terdiri dari sub tema yaitu kewajiban petugas, dan sikap petugas. Kewajiban merupakan sesuatu yang harus diperbuat atau harus dilakukan oleh seseorang. Sedangkan menurut Kamus Besar Bahasa Indonesia kewajiban adalah sesuatu yang wajib dilaksanakan, keharusan (sesuatu hal yang harus dilaksanakan). Kewajiban dibagi atas dua macam, yaitu kewajiban sempurna yang selalu berkaitan dengan hak orang lain dan kewajiban tidak sempurna yang tidak terkait dengan hak orang lain. Kewajiban sempurna mempunyai dasar keadilan, sedangkan kewajiban tidak sempurna beradasarkan moral. Dalam Peraturan Pemerintah Nomor 32 Tahun 1996 Pasal 22 ayat (1), dinyatakan bahwa bagi tenaga kesehatan jenis tertentu dalam melaksanakan tugas profesinya berkewajiban untuk : menghormati hak pasien; menjaga kerahasiaan identitas dan tata kesehatan pribadi pasien, memberikan informasi yang berkaitan dengan kondisi dan tindakan yang akan dilakukan, meminta pesetujuan terhadap tindakan yang akan dilakukan, membuat dan memelihara rekam medis. Kewajiban petugas dalam memberikan pelayanan kepada pasien, dinilai cukup baik oleh partisipan. Partisipan merasa diberikan pelayanan yang baik oleh petugas. Partisipan merasakan diberikan pelayanan yang baik dan dihargai, ketika datang ke IGD langsung diberikan penanganan oleh perawat dan tidak diterlantarkan.

Namun disisi lain, partisipan menilai berbeda terhadap kewajiban petugas kesehatan. Partisipan merasa patugas tidak melaksanakan kewajibannya dengan baik, dengan tidak memberikan informasi yang berkaitan dengan sesuatu yang harus dilakukan ketika partisipan pulang ke rumah, sedangkan petugas yang berjaga diruangan tidak melakukan rutinitas, hanya duduk duduk di ruangan. Pasien menjadi bingung terhadap apa yang harus dilakukan di rumah, apa yang tidak 
diperbolehkan, serta apa yang tidak diperbolehkan.

Sikap petugas pada saat memberikan pelayanan kepada pasien, dinilai baik oleh partisipan. Sebelum melakukan tindakan, perawat meminta izin kepada pasien, meskipun terkadang tidak memberikan salam, tapi bagi pasien tidak menjadikan suatu permasalahan. Partisipan merasakan privasinya dijaga selama dirawat di IGD oleh petugas kesehatan. Ketika pasien dilakukan pemeriksaan yang membutuhkan dibuka baju, petugas menyikapi hal tersebut dengan menutup pintu dan hanya pasien dan petugas itu saja.

Kebutuhan kenyamanan sosiokultural adalah kebutuhan untuk sensitif budaya dan bahasa tubuh yang positif. Perawat dapat memberikan kebutuhan tersebut melalui pembinaan, dorongan, persahabatan dan penjelasan prosedur.

\section{Lingkungan yang nyaman}

Lingkungan merupakan suatu kondisi yang ikut berperan dalam proses penatalaksanaan pasien di IGD. Tema lingkungan yang nyaman dibentuk dari dua sub tema, yaitu kondisi ruangan dan situasi kondusif.

Gedung IGD yang sekarang ditempati, merupakan bangunan yang baru selesai dalam pembangunan. Partisipan merasakan kenyamanan ketika memasuki dan tinggal beberapa saat untuk dilakukan tindakan di ruangan. Keadaan lingkungan yang nyaman, bersih, wangi, tidak bau obat, terasa dingin, dan kamar mandi juga bersih. Petugas cleaning service setiap ikut shift dinas, sehingga ketika ada darah atau cairan yang mengotori lantai segera dapat diatasi.

Suasana ruangan merupakan sub tema kedua setelah kondisi ruangan pada tema situasi (lingkungan). Suasana yang kondusif dirasakan partisipan ketika menjalani perawatan di IGD. Penghuni yang ada di ruangan hanya petugas dan pasien, penunggu pasien ditempatkan sendiri tepat di pintu keluar green zone.
Namun ada partisipan yang merasakan berbeda terhadap suasana lingkungan, karena berfokus pada kondisinya pada saat itu, ketika pasien sedang terfokus dengan keadaannya.

Kebutuhan kenyamanan pasien dapat berupa lingkungan yang tenang dan nyaman. Perawat dapat membantu pasien mencapai kenyamanan dengan menutup pintu/tirai pembatas pasien, meminimalkan gangguan saat pasien istirahat, dan mengurangi suara keras di sekitar pasien (Kolcaba, 2001).

\section{Kenyamanan}

Kenyamanan (comfort) merupakan bagian penting dari pengobatan dan pemulihan pasien secara fisik dan mental (Peterson \& Bredow, 2009). Dalam teorinya Kolcaba menggambarkan kenyamanan holistik sebagai pengalaman langsung dalam tiga bentuk yang berbeda : pemenuhan kebutuhan (relief), ketenangan (ease), dan pencapaian individu di atas masalahnya (transendensi) (March \& McCormack, 2009). Ketiga bentuk kenyamanan tersebut bertemu dalam empat konteks, yaitu : fisik, psikospritual, sosial budaya dan lingkungan (Goodwin et al, 2007).

Keinginan mendasar dari pasien prioritas paling rendah yang datang di IGD adalah kenyamanan. Pasien menginginkan kenyamanan secara menyeluruh, baik dalam pemenuhan kebutuhan terhadap kesehatan ataupun ketenangan selama dirawat. Kenyamanan dalam pemenuhan kebutuhan melalui proses pemeriksaan, tindakan sampai dengan dievaluasinya tindakan pada pasien. Ketenangan pada pasien dilakukan dengan memberikan suasana yang kondusif pada saat perawatan dengan menjaga ketenangan ruangan, membatasi pengunjung, dan meningkatkan privasi pasien.

Keinginan mendasar dari pasien prioritas paling rendah yang datang di IGD adalah kenyamanan. Pasien menginginkan kenyamanan secara menyeluruh, baik dalam pemenuhan 
kebutuhan terhadap kesehatan ataupun ketenangan selama dirawat. Kenyamanan dalam pemenuhan kebutuhan melalui proses pemeriksaan, tindakan sampai dengan dievaluasinya tindakan pada pasien. Ketenangan pada pasien dilakukan dengan memberikan suasana yang kondusif pada saat perawatan dengan menjaga ketenangan ruangan, membatasi pengunjung, dan meningkatkan privasi pasien.

Kenyamanan dirasakan hampir semua pasien prioritas paling rendah. Kenyaman tampak ketika pasien membicarakan tentang lingkungan IGD, meskipun mereka sedikit kecewa dengan beberapa hal. Beberapa hal yang membuat pasien kecewa diantaranya managemen obat yang menyebabkan pasien harus menunggu lama dalam pengambilan obat serta kurangnya komunikasi petugas kesehatan mengenai kondisi pasien. Beberapa dari partisipan memaklumi apabila ada beberapa kekurangan dalam pelayanan. Meskipun situasi IGD ramai, petugas tetap langsung memberikan penanganan kepada mereka. Hal tersebut semakin menambah kenyamanan pasien ketika dirawat di IGD.

\section{KESIMPULAN}

Berdasarkan hasil penelitian dan uraian pembahasan pada bab sebelumnya, maka dapat disimpulkan bahwa pada pengalaman pasien prioritas paling rendah di IGD didapatkan waktu tunggu yang lama pada saat pengambilan obat dan administrasi pembayaran, prosedural yang tidak menyulitkan bagi pasien, serta lingkungan yang nyaman dan mendukung pengobatan. Meskipun didapatkan beberapa keluhan akan tetapi kenyamanan tetap dirasakan pasien dalam pemenuhan kebutuhan fisik atau kesehatan, maupun ketenangan dalam kontak psikososial atau lingkungan. Beberapa catatan yang dapat dijadikan masukan untuk peningkatan kualitas pelayanan di IGD, diantaranya penurunan waktu tunggu di pengambilan obat, serta peningkatan komunikasi dari petugas kesehatan ke pasien

Hasil penelitian ini dapat dijadikan rujukan penelitian selanjutnya baik penelitian kualitatif maupun kuantitatif. Beberapa penelitian lanjutan bisa direkomendasikan peneliti, seperti pengaruh pemberian pendidikan kesehatan terhadap kecemasan pasien prioritas paling rendah

\section{KEPUSTAKAAN}

Ackerman S, Bingissen MB, Heierle A, Langewits W, Hertwig R, \& Bingisser R. 2012. Discharge communication in the emergency departement: physicians underestimate the time needed. Swiss Med Wkly, 2012;142:w13588

Afilalo J, Marinovich A, Afilalo M, Colacone A, Léger R, Unger B, \& Giguère C. 2004. Nonurgent emergency department patient characteristics and barriers to primary care. Acad Emerg Med, 11:1302-10.

Agency for Healthcare Administration. 2007. Emergency department report. Tallahassee, FL: Author.

Australasian College for Emergency Medicine. 2005. Guidelines for implementation of the Australasian Triage Scale in Emergency Departments. ABN 76 $009090713,1-2$

Brown J, Benton G, Daly S, Dilley S, Julie F, Goding S, Christin H, Mira I, Kambourakis T, Bill M, Standen P, Stewart C, Scully AM, \& Simon Y. 2001. Guidelines for triage education and practice. Victoria : Monash Medical Center. 
Carret ML, Fassa AG, \& Kawachi I. 2007. Demand for emergency use health service: factors associated with inappropriate use. $B M C$ Health Serv Res, 18:131.

Goodwin M, Sener, I., \& Steiner, S. H. 2007. A novel theory for nursing education: Holistic comfort. Journal of Holistic Nursing, 25(4), 278-285.

Kolcaba K. 2001. Evolution of the mid range theory of comfort for outcomes research. Nursing Outlook, 49(2), 86-92.

Kripalani S, LeFevre F, Phillips CO, Williams MV, Basaviah $\mathrm{P}$, \& Baker DW. Deficits in communication and information transfer between hospital-based and primary care physicians: implications for patientsafety and continuity of care. JAMA. 2007;297(8):831-41.

Manitoba Health-Emergency Medical Services. 2010. emergency treatment guidelines general. Journal of Emergency Nursing, $1-2$

March A \& McCormack, D. 2009. Nursing theory-directed healthcare: Modifying kolcaba's comfort theory as an institutionwide approach. Holistic Nursing Practice, 23(2), 75-82.

Peterson S \& Bredow T. 2009. Middle range theories : application to nursing research. Philadelphia, PA : Wolters Kluwer

Rakhmat \& Jalaludin. (2005). Psikologi Komunikasi. Bandung: PT. Remaja Rosda Karya

Spencer R, Logan P, \& Coiera E. 2002. Supporting Communication in the Eergency Departement. Sydney : UNSW

Tomey \& Alligood. 2006. Nursing theorist and their work, sixth edition. Toronto : The CV Mosby Company St. Louis

Vertesi L. 2004. does the canadian emergency department triage and acuity scale identify non-urgent patients who can be triaged away from the emergency department? CJEM. 6:337-42. 